\title{
Mitigation and Adaptation Strategies - Organic Agriculture
}

\section{The concept of organic farming in the context of climate change}

> Organic farming intensifies farm-internal processes like biological activities of soils, recycling of livestock and crop waste, enhanced biodiversity as well as nitrogen fixation and improved phosphorous availability by symbiosis.

> Thus, reliance on high energy external inputs is reduced and less negative externalities occur.

> Organic farming diversifies farm organisation by more complex crop rotations, by more farm activities and by deploying more knowledge.

> Thus, productivity gets higher, yields are more stable and farms become less vulnerable to climate change.

> Organic farming builds up soil fertility and increases or conserves soil organic matter.

> Thus, synchronizing supply and demand of nutrients, conserving water and sequestering $\mathrm{CO}_{2}$ into the soil.

\section{Carbon sequestration on organic farms}

Comparison of soil carbon gains and losses in different farming systems in long term field experiments

\begin{tabular}{|c|c|c|c|}
\hline Field trial & Components compared & $\begin{array}{l}\text { Carbon gains } \\
\text { (+) or losses } \\
(-) \mathbf{k g ~ h a}^{-1} \mathbf{y r}^{-1}\end{array}$ & $\begin{array}{l}\text { Relative yields } \\
\text { of the respec- } \\
\text { tive crop rota- } \\
\text { tions }\end{array}$ \\
\hline \multirow{4}{*}{$\begin{array}{l}\text { DOK Experiment, CH } \\
\text { (Mäder, et al., 2002; } \\
\text { Fließbach, et al. 2007) } \\
\text { Running since } 1977\end{array}$} & Organic, FYM composted & 42 & $83 \%$ \\
\hline & Organic, FYM fresh & -123 & $84 \%$ \\
\hline & $\begin{array}{l}\text { IP, FYM fresh, mineral } \\
\text { fertilizer }\end{array}$ & -84 & $100 \%$ \\
\hline & $\mathrm{IP}$, mineral fertilizer & -207 & $99 \%$ \\
\hline \multirow{2}{*}{$\begin{array}{l}\text { SADP, USA } \\
\text { (Teasdale, et al., 2007) } \\
\text { Running } 1994 \text { to } 2002\end{array}$} & Organic, reduced till & +819 to +1738 & $83 \%$ \\
\hline & Conventional, no till & 0 & $100 \%$ \\
\hline \multirow{3}{*}{$\begin{array}{l}\text { Rodale FST, USA, } \\
\text { (Hepperly, et al., 2006; } \\
\text { Pimentel, et al., 2005) } \\
\text { Running since 1981 }\end{array}$} & Organic, FYM & 1218 & $97 \%$ \\
\hline & Organic, legume based & 857 & $92 \%$ \\
\hline & Conventional & 217 & $100 \%$ \\
\hline Frick Reduced Tillage & Organic, ploughing & 0 & $100 \%$ \\
\hline $\begin{array}{l}\text { Experiment, CH } \\
\text { (Berner, et al., 2008) } \\
\text { Running since } 2002\end{array}$ & Organic, reduced tillage & 879 & $112 \%$ \\
\hline Scheyern Experimental & Organic & 180 & $57 \%$ \\
\hline $\begin{array}{l}\text { Farm, D } \\
\text { (Rühling, et al. 2005), } \\
\text { Running since } 1990\end{array}$ & Conventional & -120 & $100 \%$ \\
\hline
\end{tabular}

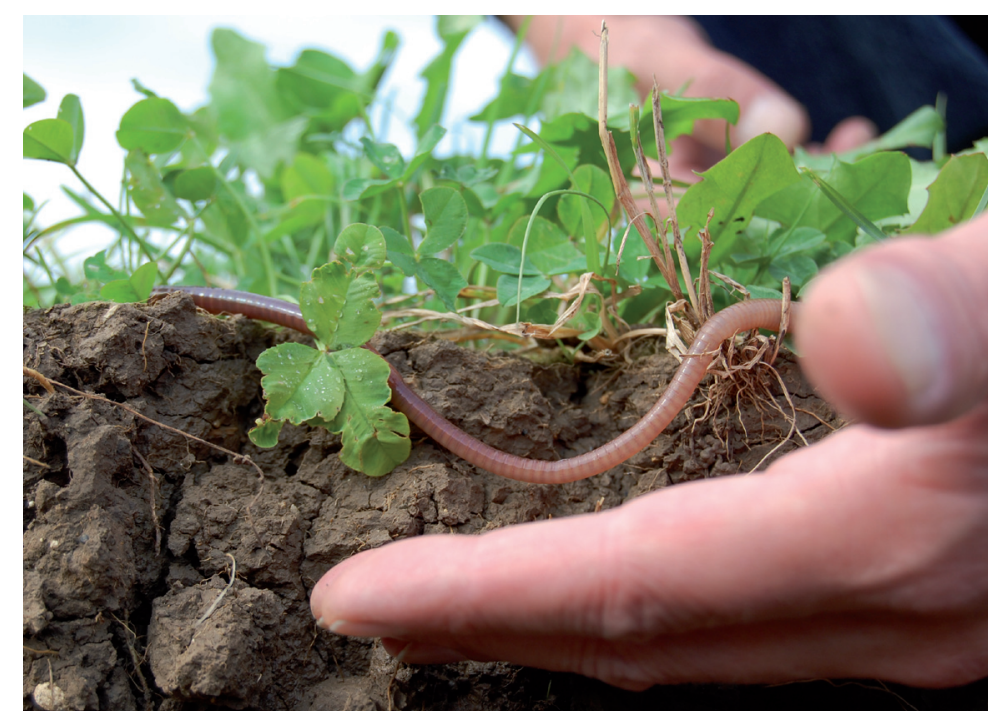

\section{Is low GHG emission agriculture possible?}

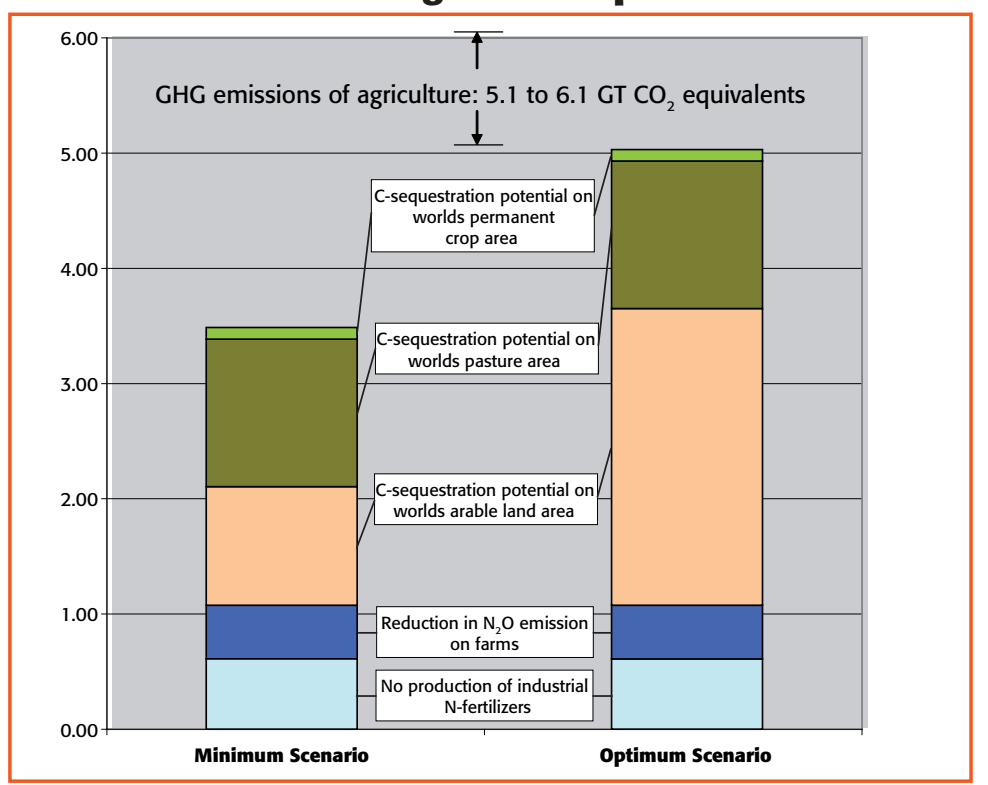

GHG reduction and mitigation potential in the agricultural sector (scenarios) The GHG emissions of agriculture amount at $5.1-6.1 \mathrm{Gt} \mathrm{CO}_{2}$-equivalents (top graph). With improved farm and crop management, most of these emissions could be reduced or compensated by sequestration. A conversion to organic agriculture would reduce industrial $\mathrm{N}$-fertilizer use that emits $6.7 \mathrm{~kg} \mathrm{CO}$-eq per $\mathrm{kg} \mathrm{N}$ on manufacture and another 1.6 percent of the applied $\mathrm{N}$ as soil $\mathrm{N}_{2} \mathrm{O}$ emission. It could also enhance the sequestration of $\mathrm{CO}_{2}$ into the soils in a considerable way. For the minimum scenario, we took a sequestration rate of $200 \mathrm{~kg} \mathrm{C} \mathrm{ha-1} \mathrm{yr-1} \mathrm{for} \mathrm{arable} \mathrm{and} \mathrm{permanent} \mathrm{crops} \mathrm{and} 100 \mathrm{~kg} \mathrm{C}$ ha-1 yr-1 for pastures. The maximum scenario combines organic farming with reduced tillage on arable land (sequestration rate $500 \mathrm{~kg} \mathrm{C}$ ha-1 yr-1).

\section{Consequences of an area-wide conversion to organic agriculture}

Organic agriculture is less productive than input-intensive food production. Strengths of organic systems are:

> Organic agriculture halts erosion caused by wind and water as well as by overgrazing - a loss rate of 10 million hectare annually (Pimentel, 1995).

> Organic agriculture rehabilitates poor soils, restores organic matter content and bring such soils back into productivity.

> Organic farming productivity is higher than often criticised: Under best geo-climatic conditions, it is -30 to $-40 \%$. In less favourable areas, its productivity tends to be equal to conventional farming. In regions with drought or subsistence agriculture, organic farming is superior $(+112 \%)$.

> Organic agriculture is based on lower livestock densities and can compensate for lower yields by a more effective vegetable production (land use ratio 1:7 for vegetable and animal production).

> The potential productivity of organic farms and organically managed landscape can be further improved by scientific agroecological research.

> Organic agriculture offers many added benefits: increased biodiversity, reduced environmental impacts, improved livelihoods due to high value food chains.

For references:

Niggli, U., Fließbach, A., Hepperly, P. and Scialabba, N. (2009) Low Greenhouse Gas Agriculture: Mitigation and Adaptation Potential of Sustainable Farming Systems. FAO, May 2009, Rev. 1 - 2009. 18 pages. (ftp://ftp.fao.org/docrep/fao/010/ai781e/ai781 e00.pdf) 